\title{
Analisis Kesulitan Siswa dalam Proses Pemecahan Masalah GEOMETRI BERDASARKAN TAHAPAN BERPIKIR VAN HIELE
}

[Penelitian Studi Kasus di Kelas VII SMP Negeri 6 Garut]

\section{Students' Difficulties Analysis in Problem Solving Process of Geometry BaSed ON VAN Hiele Thinking STAGeS \\ [Case Study Research in Class VII SMP Negeri 6 Garut]}

\author{
Silfi Zainatu Sholihah ${ }^{1}$ dan Ekasatya Aldila Afriansyah ${ }^{2}$ \\ 1 Program Studi Pendidikan Matematika, STKIP Garut \\ Garut, Jawa Barat, Indonesia \\ Silvi.zaina@gmail.com \\ 2 Program Studi Pendidikan Matematika, STKIP Garut \\ Garut, Jawa Barat, Indonesia \\ e_satya@yahoo.com
}

\begin{abstract}
Abstrak
Matematika memiliki peranan penting dalam kehidupan. Namun, dalam praktik pembelajarannya sebagian siswa masih menganggap matematika sebagai mata pelajaran yang sulit. Bukti-bukti di lapangan menunjukkan bahwa hasil belajar geometri masih rendah. Kesulitan pada materi geometri dapat berdampak pada kesulitan-kesulitan bagian lain dalam materi geometri itu sendiri, karena banyak pokok bahasan dalam geometri yang saling berhubungan. Penelitian ini bertujuan untuk mengetahui faktor penyebab kesulitan siswa dalam proses pemecahan masalah geometri berdasarkan tahapan berpikir Van Hiele serta untuk melihat ketercapaian siswa dalam pemahaman geometri berdasarkan tahapan berpikir geometri Van Hiele. Metode penelitian yang digunakan adalah metode penelitian kualitatif dengan jenis penelitian studi kasus. Subjek penelitian yang diambil sebanyak 6 siswa dari kelas VII C SMP Negeri 6 Garut. Hasil penelitian menunjukkan bahwa ketercapaian siswa pada proses pemecahan masalah geometri berdasarkan tahapan berpikir Van Hiele paling banyak adalah pada tahap 0 (visualisasi). Hal ini ditunjukkan dengan tingginya persentase pencapaian siswa pada tahap visualisasi yaitu sebanyak 96,87 \%. Ketercapaian tahapan berpikir Van Hiele yang paling baik dicapai sebesar 3,13\% pada tahap 1 (Analisis). Untuk tahap 2 (deduksi informal) dan tahap 3 (deduksi) belum ada siswa yang mampu mencapai tahapan tersebut. Faktor yang menjadi penyebab kesulitan siswa dalam materi segiempat disebabkan karena beberapa hal, yaitu pemahaman mengenai konsep dan sifat-sifat segiempat yang kurang, pemahaman sebelumnya mengenai materi bangun datar segiempat yang masih kurang kuat, kurangnya keterampilan menggunakan ide-ide geometri dalam memecahkan masalah matematika yang berkaitan dengan bangun segiempat, serta kondisi kelas yang kurang kondusif untuk belajar.

Kata Kunci: Kesulitan siswa pada geometri, tahapan berpikir Van Hiele, Kualitatif, Studi Kasus.
\end{abstract}

\begin{abstract}
Mathematics has an important role in life. However, in the practice of learning some students still regard mathematics as a difficult subject. The evidence in the field shows that the geometry learning result is still low. Difficulties in geometrical matter can affect the difficulties of other parts of the material itself, since many of the subjects in the geometry are interconnected. This study aims to determine the factors causing student difficulties in the process of solving geometry problems based on the stages of thinking Van Hiele and to see students' achievement in
\end{abstract}


understanding geometry based on the stages of thinking geometry Van Hiele. The research method used is qualitative research method with case study research type. Research subjects taken as many as 6 students from class VII C SMP Negeri 6 Garut. The results showed that students' achievement in the process of solving geometry problems based on the stage of thinking Van Hiele at most is at stage 0 (visualization). This is indicated by the high percentage of student achievement in the visualization stage that is as much as $96.87 \%$. The achievement of the best stage of Van Hiele thinking was achieved at 3.13\% in stage 1 (Analysis). For stage 2 (informal deduction) and stage 3 (deduction) no students have been able to reach that stage. Factors that cause student difficulties in rectangular material caused by several things, namely the understanding of the concept and the characteristics of the rectangle is lacking, previous understanding of the material wake rectangular flat that is still less strong, the lack of skills to use geometric ideas in solving math problems Relating to wake up quadrilateral, as well as class conditions that are less conducive to learning.

Keyword: Student difficulties on geometry, Van Hiele thinking stages, Qualitative, Case Studies.

\section{Pendahuluan}

Matematika merupakan salah satu mata pelajaran pokok yang dipelajari di setiap jenjang pendidikan di sekolah mulai dari SD, SMP, hingga SMA. Hal ini karena matematika memegang peranan penting dalam kehidupan terutama dalam memecahkan permasalahan sehari-hari. Hal ini ditegaskan oleh Hendriana dan Soemarmo (2014:1) yang menyatakan bahwa "... setiap orang dalam kegiatan hidupnya akan terlibat dengan matematika, mulai dari bentuk yang sederhana dan rutin sampai pada bentuknya yang sangat kompleks." Cockroft (Ehan,1983:1-5) mengemukakan bahwa matematika perlu diajarkan kepada siswa karena:

a. Selalu digunakan dalam segi kehidupan

b. Semua bidang studi memerlukan keterampilan matematika yang sesuai

c. Merupakan sarana komunikasi yang kuat, ringkas dan jelas. d. Dapat digunakan untuk menyajikan informasi dalam berbagai cara.

e. Meningkatkan kemampuan berpikir logis, ketelitian dan kesadaran keruangan.

Matematika memiliki peranan penting dalam kehidupan, dalam praktik pembelajarannya sebagian siswa masih menganggap matematika sebagai mata pelajaran yang sulit. Hal ini dibuktikan dengan hasil survey yang dilakukan Trend in International Mathematics and Science Study (TIMSS) dan Program International Student Assessment (PISA) tentang kemampuan matematika siswa di Dunia :

"Hasil penilaian TIMSS tahun 2011 lebih dari 95\% siswa Indonesia hanya mampu sampai level menengah, jauh lebih rendah dari negara-negara ASEAN yang lain seperti Thailand, Malaysia, dan Singapura.Pada hasil PISA tahun 2012 indonesia hanya menempati peringkat ke 64 dari 65 negara dimana Indonesia hanya lebih baik dari Peru yang merupakan peringkat ke 65". (Berita Pilihan PPPPTK, 2015) 
Kebanyakan siswa masih mengalami kesulitan dalam menerapkan rumusrumus, memahami teorema-teorema, bahkan yang paling utama siswa masih mengalami kesulitan dalam memahami permasalahan dalam suatu soal matematika. Berdasarkan penelitian yang dilakukan Yeo (dalam Wijayanti, 2016) di Singapura yang meneliti tentang kesulitan yang dialami siswa kelas VIII dalam memecahkan masalah matematika menyebutkan bahwa kesulitan yang dialami oleh siswa ketika memecahkan masalah matematika adalah kesulitan dalam: (a) memahami masalah yang diberikan (lack of comprehension of the problem posed), (b) menentukan strategi penyelesaian yang tepat (lack of comprehension of strategy knowledge), (c) membuat model matematika (inability to translet the problem into mathematical form), dan (d) melakukan prosedur matematika yang benar (inability to use the correct mathematics). Menurut Slameto (2013: 54-72) "Kesulitan tersebut bisa disebabkan karena dua faktor : Faktor internal seperti jasmani,psikologi, dan kelelahan, dan faktor eksternal yaitu keluarga, sekolah, dan lingkungan masyarakat".

Salah satu bagian penting dalam matematika adalah geometri. Dalam beberapa materi geometri selalu menjadi bahasan yang menarik. Chairani (2013) menyatakan bahwa "Melalui pengalaman belajar geometri dapat meningkatkan keterampilan pemecahan masalah, penalaran dan kemudahan dalam mempelajari berbagai topik matematika, serta berbagai ilmu pengetahuan yang lain. Pembelajaran geometri juga dapat meningkatkan minat anak terhadap matematika, meningkatkan keterampilan pemecahan masalah, penalaran dan kemudahan dalam mempelajari berbagai topik matematika serta ilmu yang lain."

Geometri juga merupakan salah satu bagian dari materi matematika yang memiliki hubungan yang erat dengan bagian-bagian lain dalam matematika. Geometri digunakan oleh setiap orang dalam kehidupan sehari-hari. Dalam kehidupan nyata geometri banyak bermanfaat dalam bidang teknik, geografi dan bidang-bidang lainnya. Hal ini sesuai dengan pendapat Van de Walle (dalam Abdussakir,2013:269) yang menyatakan bahwa "Ilmuwan, arsitek, artis, insinyur, dan pengembang perumahan adalah sebagian kecil contoh profesi yang menggunakan geometri secara reguler. Dalam kehidupan sehari-hari, geometri digunakan untuk mendesain rumah, taman, atau dekorasi".

Tujuan pembelajaran geometri adalah agar siswa memperoleh rasa percaya diri mengenai kemampuan matematikanya, menjadi pemecah masalah yang baik, dapat berkomunikasi secara matematik, dan dapat bernalar secara matematik. Menurut Budiarto (dalam Abdussakir, 2013:439) menyatakan bahwa "Tujuan pembelajaran geometri adalah untuk mengembangkan kemampuan berpikir logis, mengembangkan intuisi keruangan, 
menanamkan pengetahuan untuk menunjang materi yang lain, dan dapat membaca serta menginterpretasikan argumen-argumen matematik".

Geometri yang dipelajari di sekolah meliputi geometri murni, geometri analitik dan transformasi. Setiap tahapan dipelajari mulai dari jejang SD sampai ke SMA, mulai dari mempelajari geometri murni, kemudian geometri analitik lalu transformasi geometri.

Pada dasarnya, geometri mempunyai peluang yang lebih besar untuk dipahami siswa dibandingkan dengan cabang matematika yang lain. Hal ini dikarenakan ide-ide geometri sudah dikenal oleh siswa sejak sebelum mereka masuk sekolah, misalnya garis, bidang, dan ruang. Meskipun demikian, bukti-bukti di lapangan menunjukkan bahwa hasil belajar geometri masih rendah. Pada kenyataannya, dalam mempelajari matematika terutama yang berkaitan dengan geometri, ternyata banyak siswa yang masih merasa kesulitan. Kesulitan pada bagian-bagian dalam geometri bisa berdampak pada kesulitan-kesulitan bagian lain dalam geometri karena banyak pokok bahasan dalam geometri yang saling berhubungan. Berdasarkan hasil penelitian yang dilakukan oleh Kusniati (2011) diketahui bahwa :

"Pencapaian tingkat perkembangan berpikir geometri menurut teori Van Hiele dari 38 anak didapatkan 28 anak berada pada tingkat 0 (visualisasi), 9 anak berada pada tingkat 1 (analisis), dan 1 anak berada pada tingkat deduksi informal.
Jenis kesalahan yang paling banyak dilakukan oleh subjek penelitian adalah kesalahan konsep. Hal ini dikarenakan pemahaman konsep segiempat yang kurang. Sehingga untuk mengurangi banyaknya kesalahan konsep yang dilakukan siswa pada materi pokok segiempat, perlu mempertimbangkan kemampuan dan pengetahuan siswa dalam memberikan materi serta menekankan pembelajaran pada pemahaman konsep".

Untuk mengatasi kesulitan belajar khususnya dalam bidang geometri, guru berusaha menggunakan berbagai pendekatan pembelajaran sesuai dengan kondisi yang terjadi. Salahsatu pendekatan yang relevan dengan materi geometri adalah pendekatan geometri Van Hiele. Van Hiele adalah seorang guru matematika bangsa Belanda yang pada tahun 1954 menulis disertasi tentang pengajaran geometri. Disertasinya itu ditulis berdasarkan dari hasil penelitiannya di lapangan melalui observasi dan tanya jawab. la menyimpulkan bahwa terdapat lima tahap pemahaman geometri. Tahap tahap atau perkembangan mental siswa dalam memahami geometri itu adalah visualisasi, analisis, pengurutan, deduksi, dan keakuratan (rigor). (Russefendi, 2005:161-163).

Pada tahap visualisasi, siswa sudah mengenal bentuk-bentuk geometri, seperti : segitiga, kubus, bola, lingkaran dan lain-lain. Tetapi ia belum memahami sifat-sifatnya. Pada tahap analisis, Pada tahap ini, siswa sudah dapat memahami 
sifat-sifat konsep atau bentuk geometri. Misalnya, siswa mengetahui dan mengenal bahwa sisi persegi panjang yang berhadapan itu sama panjang, bahwa panjang kedua diagonalnya sama panjang dan memotong satu sama lain sama panjang, dan lain-lain. Tetapi ia belum bisa memahami hubungan antara bentukbentuk geometri itu misalnya, bujur sangkar itu adalah persegi panjang, belah ketupat, jajar genjang, trapesium, dan segi empat.

Tahap selanjutnya yaitu tahap pengurutan, selain siswa sudah mengenal bentuk-bentuk geometri dan memahami sifat-sifatnya juga ia sudah bisa mengurutkan bentuk-bentuk geometri dan memahami sifat-sifatnya juga ia sudah bisa mengurutkan bentuk bentuk geometri yang satu sama lain berhubungan. Walupun begitu, siswa pada tahap ini berpikir secara deduktifnya belum berkembang ; baru mulai. Karena itu dalam mengenalnya bahwa panjang kedua diagonalnya persegipanjang itu sama misalnya, mungkin belum bisa menjelaskannya mengapa itu sama panjang.

Pada tahap deduksi ini, berpikir deduktifnya sudah mulai tumbuh, tetapi belum berkembang dengan baik. Pada tahap ini siswa sudah dapat memahami pentingnya mengambil kesimpulan secara deduktif, karena misalnya siswa dapat melihat bahwa kesimpulan yang diambil secara induktif itu mungkin bisa keliru. Pada tahap ini, juga siswa sudah dapat memahami pentingnya unsur-unsur yang tidak didefinisikan. Adapun tahap terakhir, yaitu tahap keakuratan (rigor), siswa bernalar secara formal dalam sistem matematika dan dapat menganalisis konsekuensi dari manipulasi aksioma dan definisi. Saling keterkaitan antara bentuk yang tidak didefinisikan, aksioma, definisi, teorema dan pembuktian formal dapat dipahami.

Berdasarkan jenjang kemampuan matematika siswa yang berbeda-beda dengan menggunakan acuan patokan, peneliti mengelompokan siswa kedalam 3 kelompok berpikir. Kelompok tersebut terdiri dari kelompok rendah, sedang, dan tinggi. Pengelompokan jenjang kemampuan matematika tersebut diambil dari hasil kemampuan awal matematis (KAM) siswa yang sudah diranking dari nilai yang terbesar ke nilai yang terkecil. Karena keterbatasan peneliti, dari masingmasing kelompok diambil 2 subjek penelitian. Sehingga, penelitian ini terfokus pada 6 subjek penelitian. Hal ini bertujuan untuk memudahkan peneliti dalam melakukan observasi dan membentuk kelompok yang heterogen. Karena menurut Effendi (2016) "Adanya pembagian kelompok siswa dalam pembelajaran dengan kemampuan awal matematis (KAM) yang heterogen akan mendorong terjalinnya hubungan yang saling mendukung antar anggota kelompok".

Berdasarkan hal-hal yang telah peneliti uraikan di atas, peneliti tertarik mengadakan penelitian lebih lanjut mengenai kesulitan belajar siswa dalam 
proses pemecahan masalah materi digunakan metode penelitian kualitatif geometri. Oleh karena itu, dalam dengan jenis penelitian studi kasus. penelitian ini peneliti mengambil judul : menurut Creswell (1998: 37-38) "Studi Analisis Kesulitan Belajar Siswa dalam kasus yaitu jenis penelitian yang Proses Pemecahan Masalah Geometri Berdasarkan Tahapan Berpikir Van Hiele.

Berdasarkan latar belakang yang telah dikemukakan, maka pertanyaan dalam penelitian ini adalah :

1. Bagaimanakah ketercapaian proses pemecahan masalah geometri siswa berdasarkan tingkatan berpikir Van Hiele?

2. Apa saja faktor yang menjadi penyebab kesulitan siswa dalam proses pemecahan masalah geometri pada tahapan berpikir Van Hiele?

Adapun tujuan dari penelitian ini adalah untuk :

1. Menganalisis penyebab kesulitan siswa dalam proses pemecahan masalah matematika materi geometri.

2. Mendeskripsikan letak kesulitan paling banyak yang dialami oleh siswa dalam proses pemecahan masalah matematika materi geometri.

\section{Metode}

Untuk menganalisis kesulitan siswa dalam proses pemecahan masalah geometri berdasarkan tahapan berpikir Van Hiele, sesuai dengan unsur-unsur pokok yang harus ditemukan sesuai dengan butir-butir rumusan masalah, tujuan dan manfaat penelitian, maka

memfokuskan spesifikasi kasus dalam suatu kejadian baik itu yang mencakup individu, kelompok budaya ataupun suatu potret kehidupan". Lebih lanjut Creswell mengemukakan beberapa karakteristik dari suatu studi kasus yaitu : (1) mengidentifikasi "kasus" untuk suatu studi; (2) Kasus tersebut merupakan sebuah "sistem yang terikat" oleh waktu dan tempat; (3) Studi kasus menggunakan berbagai sumber informasi dalam pengumpulan datanya untuk memberikan gambaran secara terinci dan mendalam tentang respons dari suatu peristiwa.

Pada penelitian kualitatif, tidak ada sampel acak, tetapi sampel bertujuan (purposive sample). Menurut Sugiyono (2015:53) "Sampel bertujuan (purposive sampling) adalah teknik pengambilan sampel sumber data dengan pertimbangan tertentu". Sehingga subjek yang dipilih adalah subjek yang dapat memberikan informasi sebanyak mungkin dalam penelitian ini.

Penentuan subjek penelitian didasarkan pada rangking dari nilai kemampuan awal matematis (KAM) siswa. Menurut Effendi (2016) "Dalam pembelajaran matematika kemampuan awal siswa juga turut mempengaruhi keberhasilan siswa dalam pembelajaran. Karena materi matematika pada umumnya tersusun secara hirarkis, materi yang satu merupakan prasyarat untuk materi berikutnya. Apabila siswa 
tidak menguasai materi prasyarat (KAM) maka siswa akan mengalami kesulitan dalam menguasai materi yang memerlukan materi prasyarat tersebut". Berdasarkan nilai KAM yang sudah diranking, kemudian siswa dikelompokkan menjadi 3 kelompok berdasarkan acuan patokan, yaitu kelompok tinggi, sedang dan rendah. Dari masing-masing kelompok tersebut, diambil 2 subjek penelitian untuk dibentuk menjadi kelompok diksusi yang heterogen. Karena menurut Effendi (2016) "Adanya pembagian kelompok siswa dalam pembelajaran dengan kemampuan awal yang heterogen akan mendorong terjalinnya hubungan yang saling mendukung antar anggota kelompok". Alasan dalam pemilihan subjek penelitian dalam penelitian ini adalah sebagai berikut.

1. Banyaknya subjek penelitian diserahkan sepenuhnya kepada peneliti. Dalam penelitian ini tidak dimaksudkan untuk melakukan generalisasi.

2. Karena keterbatasan peneliti, subjek penelitian yang diambil terdiri dari dua siswa dari setiap kelompok. Peneliti berpendapat bahwa dua subjek penelitian pada setiap kelompok sudah dapat memberikan informasi yang cukup dalam penelitian ini.

Data yang digunakan dalam penelitian ini adalah data primer, yaitu data yang diperoleh langsung dari subjek penelitian. Data ini merupakan data tertulis yang berasal dari hasil pekerjaan siswa pada tes tingkat perkembangan berpikir geometri Van Hiele, hasil angket terbuka, hasil observasi dan hasil wawancara dengan siswa yang menjadi subjek penelitian.

Penelitian dilaksanakan di SMP Negeri 6 Garut, yang beralamat di Jalan Bratayuda Garut, tepatnya di kelas VII-C.

Kehadiran peneliti dalam penelitian ini sangat penting, karena Menurut Sugiyono (2015:59) yang menjadi instrumen atau alat penelitian dalam penelitian kualitatif adalah peneliti itu sendiri.

Metode pengumpulan data yang digunakan untuk mendapatkan data penelitian adalah metode dokumenter, metode tes, metode wawancara dan metode pemberian angket terbuka. Pemberian angket terbuka pada penelitian ini bertujuan untuk menggali lebih dalam mengenai apa saja yang menjadi faktor penyebab kesulitan siswa dalam proses pemecahan masalahan geometri berdasarkan tahapan berpikir Van Hiele. Sehingga, dengan pemberian angket terbuka, responden lebih terbuka dalam mengungkapkan kesulitan yang dialaminya.

Metode analisis data yang dilakukan pada penelitian ini menggunakan tahapantahapan sebagai berikut :

a. Reduksi data : mengarah kepada proses menyeleksi,memfokuskan, menyederhanakan, mengabstrasikan, serta mentransformasikan data mentah yang ditulis pada catatan lapangan yang diikuti dengan perekaman (Kusniati,2011:52). 
b. Penyajian Data

Penyajian data dilakukan dengan memunculkan kumpulan data yang sudah terorganisir dan terkategori yang memungkinkan dilakukan penarikan kesimpulan. Data yang disajikan berupa hasil pekerjaan siswa, data hasil wawancara, dan hasil analisis yang berupa kesalahan setiap subjek penelitian yang merupakan data temuan.

c. Pengecekan Keabsahan Data

Menurut Moleong (2007: 327), untuk menentukan keabsahan data temuan ada beberapa teknik pemeriksaan meliputi perpanjangan keikutsertaan, ketekunan pengamatan, triangulasi, pengecekan sejawat, kecukupan referensial, kajian kasus negatif, pengecekan anggota, uraian rinci, audit kebergantungan, dan audit kepastian. Pemeriksaan keabsahan data temuan dalam penelitian ini menggunakan teknik triangulasi. Teknik triangulasi yang digunakan adalah triangulasi sumber yaitu membandingkan hasil pekerjaan siswa dengan hasil wawancara.

d. Penarikan Simpulan

Penarikan simpulan dan verifikasi dalam penelitian ini dilakukan dengan cara membandingkan analisis hasil pekerjaan siswa dan hasil wawancara sehingga dapat ditarik kesimpulan mengenai kesalahan yang dilakukan siswa dalam menyelesaikan tes.

\section{III. hasil dan Pembahasan}

Berdasarkan hasil tes diperoleh 31 anak pada tahap 0 (tahap visualisasi), dan satu orang anak pada tahap 1 (tahap analisis). Dalam penelitian ini diperoleh fakta bahwa siswa yang gagal mencapai tingkat sebelumnya, maka juga akan gagal mencapai tingkat selanjutnya. Hal ini sejalan dengan teori Van Hiele bahwa "semua anak mempelajari geometri dengan melalui tingkat-tingkat tersebut dengan urutan yang sama dan tidak dimungkinkan adanya tingkat yang diloncati". (Kusniati:106)

Berdasarkan penelitian yang telah dilakukan, diperoleh rekapitulasi ketercapaian tahapan berpikir Van Hiele:

Tabel 1.

Rekapitulasi Ketercapaian Tahapan Berpikir Geometri Van Hiele

\begin{tabular}{|ccc|}
\hline Kelompok & $\begin{array}{c}\text { Pencapaian } \\
\text { Tahapan } \\
\text { Berpikir Van } \\
\text { Hiele }\end{array}$ & $\begin{array}{c}\text { Persentase } \\
\text { Pencapaian } \\
\text { Tahapan Berpikir } \\
\text { Van Hiele }\end{array}$ \\
\hline \multirow{2}{*}{ Tinggi } & Analisis & $3,13 \%$ \\
\cline { 2 - 3 } Sedang & Visualisasi & \\
\cline { 2 - 2 } & Visualisasi & \multirow{2}{*}{$96,87 \%$} \\
\hline Rendah & Visualisasi \\
\cline { 2 - 3 } & Visualisasi & \\
\hline
\end{tabular}

Berdasarkan tabel di atas dapat dilihat bahwa ketercapaian siswa pada proses pemecahan masalah geometri berdasarkan tahapan berpikir Van Hiele paling banyak adalah pada tahap 0 
(visualisasi). Ketercapaian tahapan berpikir Van Hiele yang paling baik baru mencapai tahapan analisis (tahap 1). Untuk tahap 2 (deduksi informal) dan tahap 3 (deduksi) belum ada siswa yang mampu mencapai tahapan tersebut. Selain itu, ketercapaian tahapan berpikir geometri Van Hiele antara kelompok sedang dan rendah menunjukkan hasil yang sama. Hal ini sejalan dengan pendapat Widdiharto (2008:6) yang mengatakan bahwa "Kesulitan belajar dapat dialami oleh siswa yang berkemampuan tinggi, rata-rata dan bawah. Hal ini menegaskan bahwa siswa dari kelompok atau tingkatan manapun bisa saja mengalami kesulitan belajar". Siswa yang berada pada kelompok sedang dan rendah masih kesulitan dalam menganalisis sifat-sifat dari bangun datar segiempat, pemahaman sebelumnya mengenai materi bangun datar segiempat yang masih kurang kuat, serta kurangnya keterampilan menggunakan ide-ide geometri.

dalam memecahkan masalah
matematika yang berkaitan dengan bangun segiempat, sehingga subjek penelitian kesulitan dalam menganalisis masalah bangun datar segiempat yang diberikan dan menyebabkan siswa gagal mencapai tahapan yang lebih tinggi pada tahapan berpikir Van Hiele.

Jenis kesulitan yang dilakukan antara lain sebagai berikut:

Tabel 2.

Rincian Jenis Kesulitan Siswa dalam Proses Pemecahan Masalah Geometri

\begin{tabular}{ccccl|}
\hline Kelompok & Subjek & $\begin{array}{c}\text { No Butir } \\
\text { Soal }\end{array}$ & $\begin{array}{c}\text { Pencapaian Tahapan } \\
\text { Berpikir Van Hiele }\end{array}$ & \multicolumn{1}{c|}{ Indikator Kesulitan } \\
\hline \multirow{2}{*}{ Tinggi } & $\mathrm{S}_{1}$ & 1 & Analisis & Kesulitan menarik kesimpulan secara deduktif \\
\cline { 2 - 6 } & $\mathrm{S}_{2}$ & 1 & Visualisasi & Kesulitan menganalisis sifat-sifat (konsep) \\
\hline \multirow{2}{*}{ Sedang } & $\mathrm{S}_{3}$ & 3 & Visualisasi & Kesulitan menganalisis sifat-sifat (konsep) \\
\cline { 2 - 6 } & $\mathrm{S}_{4}$ & 4 & Visualisasi & Kesulitan menganalisis sifat-sifat (konsep) \\
\hline \multirow{2}{*}{ Rendah } & $\mathrm{S}_{5}$ & 4 & Visualisasi & Kesulitan menganalisis sifat-sifat (konsep) \\
\cline { 2 - 6 } & $\mathrm{S}_{6}$ & 3 & Visualisasi & Kesulitan menganalisis sifat-sifat (konsep) \\
\hline
\end{tabular}

Faktor penyebab kesulitan siswa dalam proses pemecahan masalah geometri Van Hiele disebabkan karena pemahaman mengenai konsep dan sifat-sifat segiempat yang kurang, pemahaman prasyarat yang belum kuat, serta kurangnya keterampilan menggunakan ide-ide geometri dalam memecahkan masalah matematika yang berkaitan dengan bangun segiempat. selain itu, faktor eksternal seperti kurang kondusifnya lingkungan belajar dikelas, lingkungan bermain, sarana dan prasana yang kurang lengkap serta jam pelajaran yang kurang efisien turut mempengaruhi kesulitan siswa dalam proses pemecahan masalah geometri berdasarkan tahapan berpikir Van Hiele.

\section{Penutup}

Berdasarkan hasil penelitian diketahui bahwa ketercapaian siswa pada proses pemecahan masalah geometri berdasarkan tahapan berpikir Van Hiele paling banyak adalah pada tahap 0 
(visualisasi). Hal ini ditunjukkan dengan tingginya persentase pencapaian siswa pada tahap visualisasi yaitu sebanyak 96,87 \%. Ketercapaian tahapan berpikir Van Hiele yang paling baik dicapai sebesar 3,13\% pada tahap 1 (Analisis). Untuk tahap 2 (deduksi informal) dan tahap 3 (deduksi) belum ada siswa yang mampu mencapai tahapan tersebut. Secara umum, pemahaman geometri siswa SMP Negeri 6 Garut berdasarkan tingkat perkembangan berpikir geometri Van Hiele masih berada pada tingkat bawah, yaitu tingkat 0 (tingkat visualisasi). Secara keseluruhan, jenis kesulitan yang dialami siswa dalam menyelesaikan soal tes pada tingkat perkembangan berpikir geometri Van Hiele yaitu kesulitan dalam menganalisis sifat-sifat dari permasalahan bangun datar geometri yang diberikan.

Faktor yang menjadi penyebab kesulitan siswa tersebut disebabkan karena beberapa hal, yaitu pemahaman mengenai konsep dan sifat-sifat segiempat yang kurang, pemahaman sebelumnya mengenai materi bangun datar segiempat yang masih kurang kuat, kurangnya keterampilan menggunakan ide-ide geometri dalam memecahkan masalah matematika yang berkaitan dengan bangun segiempat, serta kondisi kelas yang kurang kondusif untuk belajar.

Hasil penelitian ini diharapkan dapat memberikan sumbangan pemikiran sebagai usaha meningkatkan kemampuan dalam bidang pendidikan, khususnya bidang matematika.
Hasil penelitian ini hanya berlaku untuk siswa yang menjadi subjek penelitian di kelas VII SMP Negeri 6 Garut. Untuk hasil penelitian yang lebih umum diperlukan penelitian lebih lanjut. Oleh karena itu, bagi peneliti selanjutnya diharapkan melakukan penelitian lebih lanjut mengenai kesulitan siswa dalam proses pemecahan masalah geometri berdasarkan tingkat berpikir Van Hiele dengan jenjang yang lebih luas dan lebih detail.

\section{DAfTAR PUSTAKa}

Abdussakir (2011). Pembelajaran Geometri sesuai Teori Van Hiele. [online] Tersedia:https://abdussakir.wordpress .com/2011/02/09/pembelajarangeometri-sesuai-teori-van-hielelengkap/ (23 Juni 2016)

Abdur dkk. (2016). Matematika SMP/Mts Kelas VII Semester 2 Edisi Revisi.

Jakarta: Kemdikbud

Aisia Dkk. (2012). "Profil Keterampilan Geometri Siswa SMP dalam Memecahkan Masalah Geometri Berdasarkan Level Perkembangan Berfikir Van Hiele". Lentera Jurnal Ilmiah Kependidikan. No. 95

Arikunto, S. (2007). Prosedur Penelititan. Jakarta: PT Rineka Cipta

Badan Pengembangan dan Pembinaan Bahasa Kementrian Pendidikan dan Kebudayaan. (2011). Kamus Bahasa Indonesia untuk Pelajar. Jakarta: Depdiknas

Berita Pilihan PPPPTK. (2015). Informasi Sendimat III. [online] tersedia:http://p4tkmatematika.org/2 015/08/informasi-sendimat-iii/ (9 mei 2016) 
Creswell JW.(1998).Qualitative Inquiry and Research. London:SAGE Publication

Chairani, Z. (2013). Implikasi Teori Van Hiele dalam Pembelajaran Geometri. Lentera Jurnal IImiah Kependidikan.8.20-29

Djamarah, SB. (2011). Psikologi Belajar. Jakarta: PT Rineka Cipta

Effendi, H.(2016). Implementasi Model Creative Problem Solving untuk Meningkatkan Kemampuan Metakognitif Berdasarkan Kemampuan Awal Matematis Siswa. Jurnal Penelitian Pendidikan Matematika.9,No.2

Ehan.(1983).Kesulitan Belajar Matematika.[online]

Tersedia:http://file.upi.edu/direktori/fip/ju r.pend.luarbiasa/195707121984032 diakses pada (20 juni 2016)

Jamal, F. (2014). Analisis Kesulitan Belajar Siswa dalam Mata Pelajaran Matematika pada Materi Peluang Kelas Xi Ipa SMA Muhammadiyah Meulaboh Johan Pahlawan.Jurnal MAJU (Jurnal Pendidikan Matematika). Vol 1. $18-36$

Kusniati. (2011). Analisis Kesalahan Siswa dalam Menyelesaikan Soal Materi Pokok Segiempat Menurut Tingkat Berfikir Geometri Van Hiele. Skripsi pada Jurusan Matematika Universitas Semarang : Tidak diterbitkan

Moleong, L. J. 2007. Metodologi Penelitian Kualitatif. Bandung: Remaja Rosdakarya.

Mualimin, Z.(2006).Kesulitan Belajar dalam Perspektif Pendidikan.[online]

Tersedia:http://zalimin.blogspot.co.id/2010/04/kesulit an-belajar-dalam-perspektif.html $(22$ juni 2016)

Muawanah L.(2013). Analisis Kemampuan Siswa Menyelesaikan Soal Geometri
Bangun Ruang Sisi Datar berdasarkan Level Berpikir Geometri Van Hiele. Skripsi pada Fakultas Keguruan IImu Pendidikan Universitas Muhammadiyah Surakarta : tidak diterbitkan

Nurhasannah N, Dkk. (2014). Analisis Keterampilan Geometri Siswa dalam Memecahkan Masalah Geometri Berdasarkan Tingkatan Berpikir Van Hiele. Jurnal Elektronik Pembelajaran Matematika. 2,54-56

Pramudya,ND. (2016). Analisis Kesulitan Belajar Siswa Kelas VIII dalam Pembelajaran matematika dengan Menggunakan Pendekatan Scientific.Skripsi pada Jurusan Matematika dan Ilmu Pengetahuan Alam Universitas Sanata Dharma: tidak diterbitkan

Rindyana dan Chandra. (2013). Analisis Kesalahan Siswa Dalam Menyelesaikan Soal Cerita Matematika Materi Sistem Persamaan Linear Dua Variabel Berdasarkan Analisis Newman.Universitas Negeri malang : Tidak diterbitkan

Ruseffendi, ET. (2005). Pengantar Kepada Membantu Guru Mengembangkan Kompetensi Dalam Pengajaran Matematika Untuk Meningkatkan CBSA. Bandung: Tarsito.

Slameto. (2013). Belajar dan Faktor-Faktor yang Mempengaruhinya.Jakarta: PT.Rineka Cipta

Sumarmo, U. (2014). Kemampuan Pemahaman dan Penalaran Matematika Siswa SMA Dikaitkan dengan Kemampuan Penalaran logik Siswa dan Beberapa Unsur Proses Belajar Mengajar. Disertasi pada Sekolah Pasca Sarjana UPI: Tidak diterbitkan. 
Sundayana, R. (2014). Statistika Penelitian Pendidikan. Garut: STKIP Garut Press. Sugiyono, (2015). Memahami Penelitian Kualitatif. Bandung: Alfabeta

Usiskin, Z. 1982. Van Hiele Levels and Achievemant in Secondary School Geometry. Chicago: The University of Chicago.

Widdiharto, R. (2008). Diagnosis Kesulitan Belajar Matematika SMP dan Alternatif Proses Remidinya. Yogyakarta: PPPPTK Matematika

Widia, W. (2014). Analisis Kesulitan Belajar Melalui Strategi Berbasis Masalah dalam Pokok Bahasan Pertidaksamaan. Skripsi pada Jurusan Pendidikan Matematika STKIP-Garut: Tidak diterbitkan

Wijayanti, dkk. (2016). Profil Kesulitan Siswa dalam Memecahkan Masalah Matematika Materi Pokok Bangun Ruang Sisi Datar Ditinjau dari Kecerdasan Visual-Spasial Siswa.KNPM Surakarta : Universitas Muhammadiyah

Wu, D. B. \& Ma, H. L. (2006). The Distributions of Van Hiele Levels of Geometric Thinking Among 1st Through 6th Graders. Online at: http://www.emis.de/proceedings/PM E30/5/409.pdf. (Diakses 11 Desember 2016)

\section{Riwayat Hidup Penulis}

\section{Silfi Zainatu Sholihah S.Pd.}

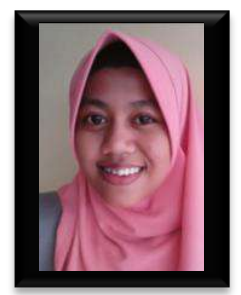

Lahir di Garut, 03 Oktober 1995. Studi S-1 Pendidikan Matematika STKIP Garut, lulus tahun 2017.

\section{Ekasatya Aldila Afriansyah, S.Si., M.Sc.}

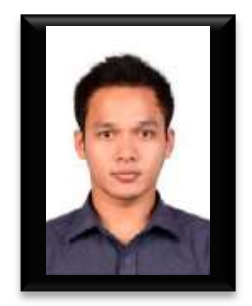

Lahir di Bandung, 4 April 1986. Dosen Tetap Yayasan STKIP Garut. Studi S1 Matematika Konsentrasi Statistika UPI, Bandung, lulus tahun 2009; S2 Pendidikan Matematika UNSRIUTRECHT, PalembangUtrecht, lulus tahun 2012; dan S3 Pendidikan Matematika UPI, Bandung, sampai sekarang. 